\title{
EEG vertè, diferencijuojant glialinị naviką ir encefalitą: klinikinio atvejo pristatymas ir literatūros apžvalga
}

\author{
M. Jokubaitis* \\ R. Mameniškiené** \\ A. Barkauskiene $\dot{*}^{* * *}$ \\ J. Valaikiené $\dot{*}^{* *}$ \\ *Vilniaus universitetas, \\ Medicinos fakultetas \\ **Vilniaus universitetas, \\ Neurologijos centras
}

***Vilniaus universiteto ligonine

Santaros klinikos, Radiologijos

ir branduolines medicinos centras

\begin{abstract}
Santrauka. Straipsnyje pristatomas klinikinis atvejis, kai iki tol sveikam 24 metu vyrui ūmus encefalitas, pasireiškęs epilepsijos priepuoliu, imitavo galvos smegenų naviką. Remiantis radiniais galvos smegenų magnetinio rezonanso tomografijoje, buvo įtartas smegenu glialinis navikas. Elektroencefalografijos (EEG) tyrimas su papildomais testais parodè funkcinio pobūdžio bioelektrinio aktyvumo sutrikimą, todẻl buvo atlikti papildomi tyrimai, leidę diagnozuoti galvos smegenų uždegimą. Minimu atveju, esant histologiškai nepatvirtintai galvos smegenų naviko diagnozei, EEG tapo svarbiausiu ịrankiu, leidusiu įtarti atipinį encefalitą. Straipsnyje taip pat apžvelgiami panašūs literatūroje aprašyti atvejai ir infekcinès bei autoimuninès kilmès encefalitams būdingi EEG pokyčiai.
\end{abstract}

Raktažodžiai: elektroencefalografija, EEG, neuroinfekcija, encefalitas, glioma, kanabinoidai.

\section{IVADAS}

Epilepsijos priepuoliais prasideda daugelio galvos smegenų navikų klinika [1]. Bent vieną epilepsijos priepuolị patiria didelẻ dalis galvos smegenų navikais sergančių pacientų, o jų pasireiškimo dažnis (1 lentelè) įvairuoja priklausomai nuo naviko tipo: priepuolius patiria 20-35\% sergančiųjų metastaziniais smegenų navikais, 20-50 \% meningioma, 40-45 \% - multiformine glioblastoma, 60-75\% ar net daugiau - žemo laipsnio (low-grade) astrocitoma ir oligodendroglioma [2]. Dažniausiai nėra sunku diagnozuoti smegenų naviką, remiantis klinikine ligos išraiška ir radiniais galvos smegenų magnetinio rezonanso tomografijos (MRT) ir 18-fluorodeoksigliukozès pozitronų emisijos tomografijos (18F-FDG-PET) tyrimuose. Ligos pradžioje gali būti sunku atskirti navikus nuo encefali-

\section{Adresas:}

Mantas Jokubaitis

Vilniaus universiteto Medicinos fakultetas

M. K. Čiurlionio g. 21, LT-03101 Vilnius

El.paštas mantas.jokubaitis1@gmail.com tų. Traukulių priepuolius ankstyvoje ligos stadijoje patiria apie 32-44 \% pacientų, sergančių virusine [3, 4], ir 23-26\%, sergančių bakterine centrinès nervų sistemos

1 lentelè. Epilepsijos priepuolių dažnumo sąsaja su galvos smegenų naviko tipu

\begin{tabular}{||l|c|l||}
\hline Naviko tipas & $\begin{array}{l}\text { Priepuolių pasi- } \\
\text { reiškimo dažnumas }\end{array}$ & $\begin{array}{l}\text { Naviko } \\
\text { lokalizacija }\end{array}$ \\
\hline $\begin{array}{l}\text { Glioneuroniniai } \\
\text { navikai (angl. glio- } \\
\text { neuronal tumors) }\end{array}$ & $70-80 \%$ & $\begin{array}{l}\text { Frontotemporaliniai, } \\
\text { salos (insula) } \\
\text { navikai }\end{array}$ \\
\hline $\begin{array}{l}\text { Žemo laipsnio } \\
\text { gliomos (angl. } \\
\text { low-grade gliomas) }\end{array}$ & $60-75 \%$ & $\begin{array}{l}\text { Frontotemporaliniai, } \\
\text { salos (insula), } \\
\text { paviršiniai navikai }\end{array}$ \\
\hline $\begin{array}{l}\text { Aukšto laipsnio } \\
\text { gliomos (angl. } \\
\text { high-grade gliomas) }\end{array}$ & $25-60 \%$ & $\begin{array}{l}\text { PSO* III laipsnio, } \\
\text { temporalinès skilties, } \\
\text { paviršiniai navikai }\end{array}$ \\
\hline Meningiomos & $20-50 \%$ & Edema aplink naviką \\
\hline $\begin{array}{l}\text { Metastaziniai } \\
\text { navikai }\end{array}$ & $20-35 \%$ & $\begin{array}{l}\text { Melanoma, plaučiu } \\
\text { věžys }\end{array}$ \\
\hline
\end{tabular}

*Pasaulio sveikatos organizacijos (PSO) CNS navikų klasifikacija

(C) Neurologijos seminarai, 2020. Open Access. This article is distributed under the terms of the Creative Commons Attribution 4.0 International License CC-BY 4.0 (http://creativecommons.org/licenses/by/4.0/), which permits unrestricted use, distribution, and reproduction in any medium, provided you give appropriate credit to the original author(s) and the source, provide a link to the Creative Commons license, and indicate if changes were made. 


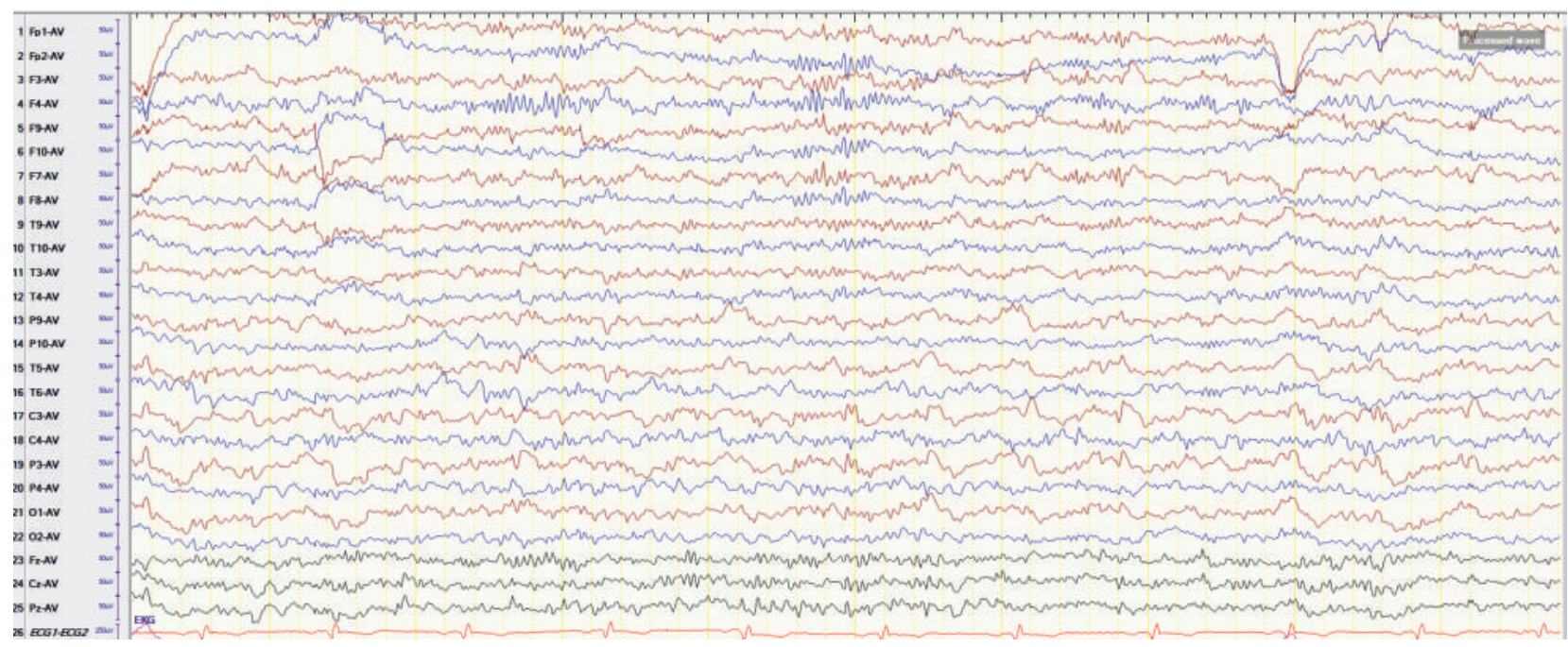

1 pav. Elektroencefalograma. „Smailokos“ teta bangos kairèje centroparietotemporalinėje srityje (C3, P3)

(CNS) infekcija [5, 6]. Šis dažnis, galimai dèl Herpes simplex-1 viruso (HSV-1) paveikiamos epileptogeninès smilkinio srities, yra didesnis: ūmius simptominius traukulius patiria 40-56 \% HSV encefalitu sergančių asmenų, dažniau - vaikai $[7,8]$.

Pristatome klinikini atveji, kai jaunam pacientui buvo įtartas galvos smegenų navikas, tačiau pakitimai elektroencefalogramoje (EEG) padèjo diagnozuoti encefalitą.

\section{ATVEJO APRAŠYMAS}

Iki tol nesirgusiam, vaistų nevartojančiam 24 metų jaunuoliui darbe staiga nevalingai pradejo drebèti dešinioji ranka ir sutriko sąmonè. Bendradarbiai vyrą rado nukritusį, trūkčiojantị. Traukuliai tęsėsi apie 3 minutes, po jų buvo dezorientuotas. Epizodo metu prikando liežuvị ir pasituštino. Greitosios medicinos pagalbos (GMP) nuvežtas į skubios pagalbos skyrių, iš kurio, po neurologo apžiūros, buvo išleistas ị namus.

Praejus trims valandoms, dar du kartus pasikartojo kelių minučių trukmės toninių-kloninių traukulių priepuoliai, po kurių pacientas hospitalizuotas ị Neurologijos skyrių skubos tvarka.

Skyriuje ligonis buvo kontaktiškas, sąmoningas ir visiškai orientuotas. Neurologinio ištyrimo metu patologinių pokyčių nestebèta, tačiau rastas saikingai padidèjęs arterinis kraujo spaudimas $(147 / 86 \mathrm{mmHg})$. Pacientas nekarščiavo (temperatūra $-36,8^{\circ} \mathrm{C}$ ), širdies veikla buvo ritmiška, širdies susitraukimų dažnis - 78 kartai per minutę.

Tikslinant anamnezę, paaiškèjo, kad ligonis prieš 10 dienų buvo peršalęs ir tris dienas karščiavo iki $38^{\circ} \mathrm{C}$, tačiau ic gydytojus nesikreipè. Tuo metu šeimoje sirgo dar du nariai. Apie 10 metu pastoviai vartojo kanapes.

Atliktuose tyrimuose (automatizuotame kraujo, elektrolitų, kreatinino, šlapalo, C reaktyvaus baltymo (CRB), kepenų fermentų, galvos smegenų kompiuterinès tomografijos (GSKT) ir ekstrakranijinių kraujagyslių sonografi- jos) patologinių pokyčių nebuvo aptikta, išskyrus saikingą leukocitozę $\left(9,94 \times 10^{9}\right.$ ląst./l).

Antrą hospitalizacijos dieną atliktoje EEG registruotas nereguliarus, silpnai moduliuotas, vidutinès amplitudès $(\sim 10 \mathrm{~Hz})$ alfa dažnio foninis aktyvumas su įsiterpiančiomis vidutinès amplitudès teta dažnio bangomis abipus temporoparietaliai, ryškiai vyraujančiomis kairèje, plintančiomis ị kairę kaktos sritį. Hiperventiliacijos mėginio metu patologinių grafoelementų nežymiai gausėjo, o fotostimuliacija papildomo patologinio aktyvumo nesukèlè (1 pav.). Atlikus galvos smegenų MRT, kairiosios kaktinės skilties precentrinio vingio apatineje dalyje stebėtas T2 hiperintensinis židinys, apimantis sustorèjusią, edemišką žievę ir požievị su neišreikšta perifokaline edema. Po intraveninio kontrastavimo pakitusioje zonoje išryškèjo keletas nedidelių kontrastinę medžiagą kaupiančių židinių. İtartas glialinis navikas (2 pav.).

Trečios hospitalizacijos dienos rytą sutriko kalba - stebèta disfazija. Bendri kraujo, CRB ir eritrocitų nusėdimo greičio rodikliai atitiko normą. Skubiai atliktoje GSKT su intraveniniu kontrastavimu naujų galvos smegenų pokyčių nenustatyta (3 pav.).

Konsultavęs neurochirurgas rekomendavo atlikti galvos smegenų MRT su spektroskopija ir traktografija, o iki tyrimų pacientui skirti gydymą deksametazonu po $8 \mathrm{mg}$ 2 kartus per parą ir manitolio infuziją $(0,5 \mathrm{~g} / \mathrm{kg}$ per parą). Vakare pasikartojo židininis motorinis traukulių priepuolis, kurio metu trūkčiojo apatinis žandikaulis, ligonis negalejo nuryti seilių. Suvokimas epizodo metu nesutriko, priepuolis baigėsi savaime per keletą minučių. Pakartota EEG su papildomomis kognityvinėmis užduotimis. Jos metu registruotas patologinis teta dažnio aktyvumas abiejuose pusrutuliuose, be aiškesnès tarppusrutulinès asimetrijos, kartais ryškesnis kairèje, kartais - dešinejje, priekinėse arba užpakalinėse srityse ir delta dažnio bangos kairèje frontotemporalinejje srityje (4 pav.). Reakcija ị užsimerkimą buvo simetriška, fiziologinė. Reakcija ị hiperventiliaciją ryškiau bioelektrinio aktyvumo (BEA) kreivès nekeitè. Hiperventiliacija, intermituojanti fotostimuliacija papildomo 


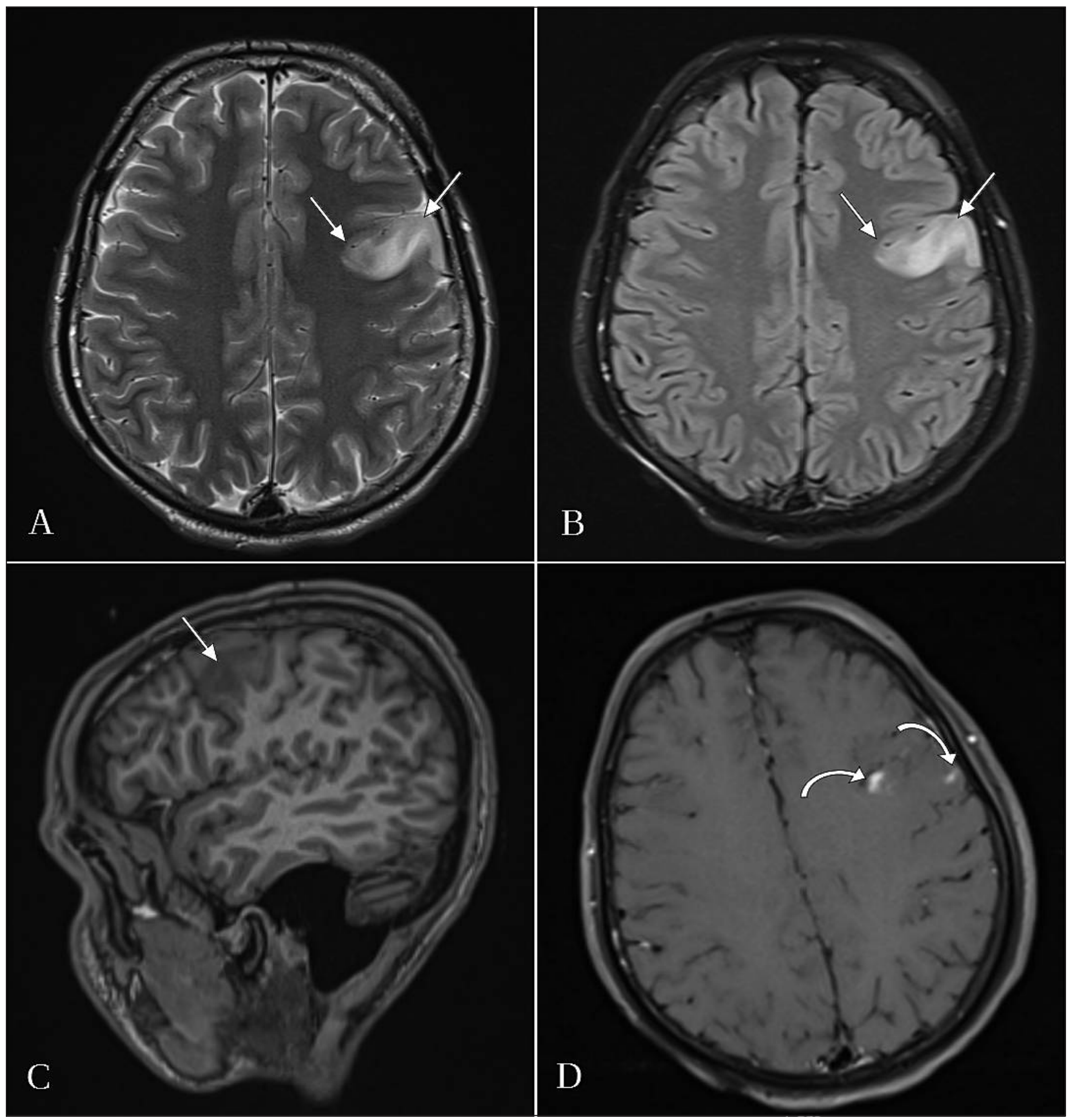

2 pav. Galvos smegenų MRT.

A - Hiperintensinė patologinė zona T2 TSE; B - T2 FLAIR sekose kairejje kaktinejje skiltyje precentrinio vingio apatinëje, operkulinėje dalyse (rodyklès); C - pakitusi hipointensinè zona T1 sagitalinėje plokštumoje (rodyklẻ); D - T1 vaizduose po kontrastavimo išryškèję keli nedideli kontrastinę medžiagą kaupiantys intarpai (lenktos rodyklès).

aktyvumo nesukèlè. Kognityvinių testų metu BEA „susinormalizavo" - išnyko dezorganizacija, registruotas alfa ir beta aktyvumas, kurio fone aiškiai išsiskyrė patologinis lokalus lètas ir epilepsiforminis aktyvumas kaireje frontotemporalinèje srityje be plitimo ị kitas sritis (5 pav.). Lyginant su ankstesniu tyrimu, „dinamika - neigiama, rodanti proceso progresavimą, kuris yra „funkcinio“ pobūdžio kognityviniai testai praeito tyrimo metu nebuvo atliekami, jų metu pagerėja foninis aktyvumas ir išryškejja lokalus patologinis aktyvumas kaireje frontotemporalinèje srityje“. Po šios EEG analizès buvo nutarta atlikti juosmeninę punkciją ir ištirti smegenų skystį.
Septintą ligos dieną, atlikus juosmeninę punkciją, gautas skaidrus likvoras su saikingu leukocitų (12 ląstelių/ $\mu 1$, vyraujant mononuklearams $(81,5 \%)$ ), gliukozès $(4,6 \mathrm{mmol} / \mathrm{l})$ kiekio padidejjimu, baltymo koncentracija normali $(0,3 \mathrm{~g} / \mathrm{l})$. Laimo boreliozès IgM antikūnų imunofermentinis tyrimas buvo teigiamas, tačiau, papildomai atlikus imunoblotą, antikūnų buvimas įvertintas kaip kryžminè reakcija. ŽIV ir sifilio tyrimai buvo neigiami. Pakartojus galvos smegenų MRT, nustatyta, kad nežymiai padidẻjo patologinis židinys kairẻje kaktinėje skiltyje, apimantis žievę ir požievị, atsirado linijinis kraštinis kaupimas žievejje. Magnetinio rezonanso spektroskopijos (MRS) re- 


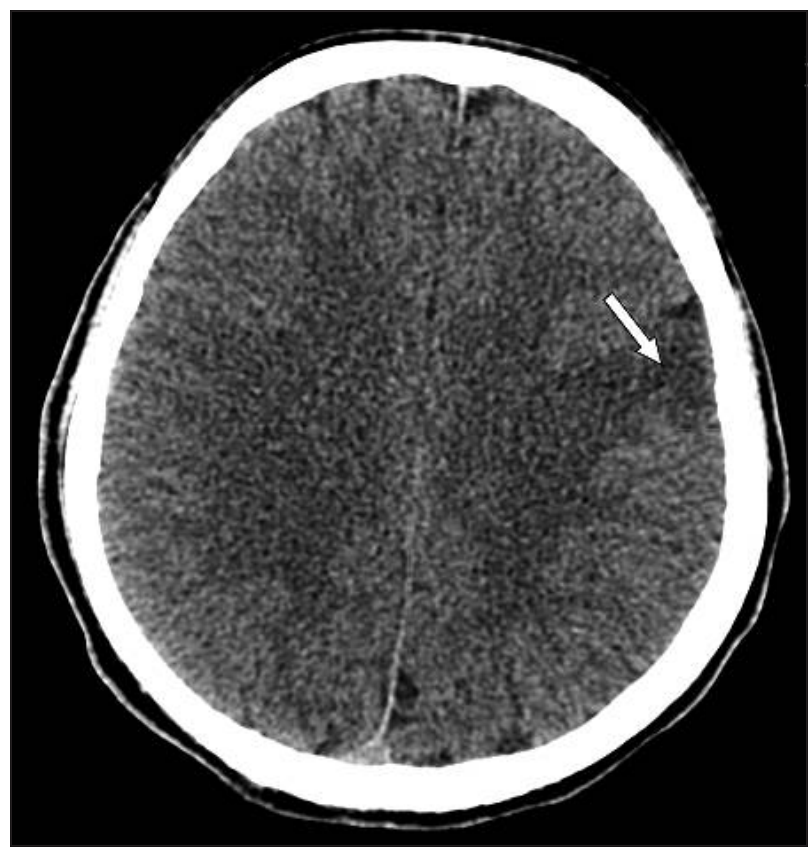

konstrukcijose ir grafikuose buvo matyti iprastinis $\mathrm{N}$-acetilaspartato (NAA), cholino (Cho) ir kreatino (Cr) koncentracijų santykis, atitinkamas dešiniojo pusrutulio simetriškai sričiai. Perfuzijos sekoje pakitusioje srityje hiperperfuzijos požymių nestebėta, CBV rodikliai, lyginant su kontralateraline puse, - panašūs. Išvada - požymių, būdingų navikui, nematyti (6 pav.).

Pakartotinio aptarimo su neurochirurgais metu nuspręsta, kad naviko diagnozė nepasitvirtino ir chirurginis gydymas nereikalingas, skirtas gydymas manitolio infuzija $(15 \% 250 \mathrm{ml})$ ị veną ir natrio valproato tabletemis (250 mg 1 kartą per parą).

Visiškai regresavus disfazijai, nesikartojant traukulių priepuoliams ir pagerẻjus bendrai būklei, vienuoliktą hospitalizacijos dieną ligonis išrašytas ị namus.

3 pav. Galvos smegenų KT.

Kairèje kaktinėje skiltyje sumažèjusio tankio zona (rodyklè) išliko panaši, lyginant su anksčiau atliktu MRT tyrimu, naujų pakitimų, pakraujavimo nebuvo stebèta.

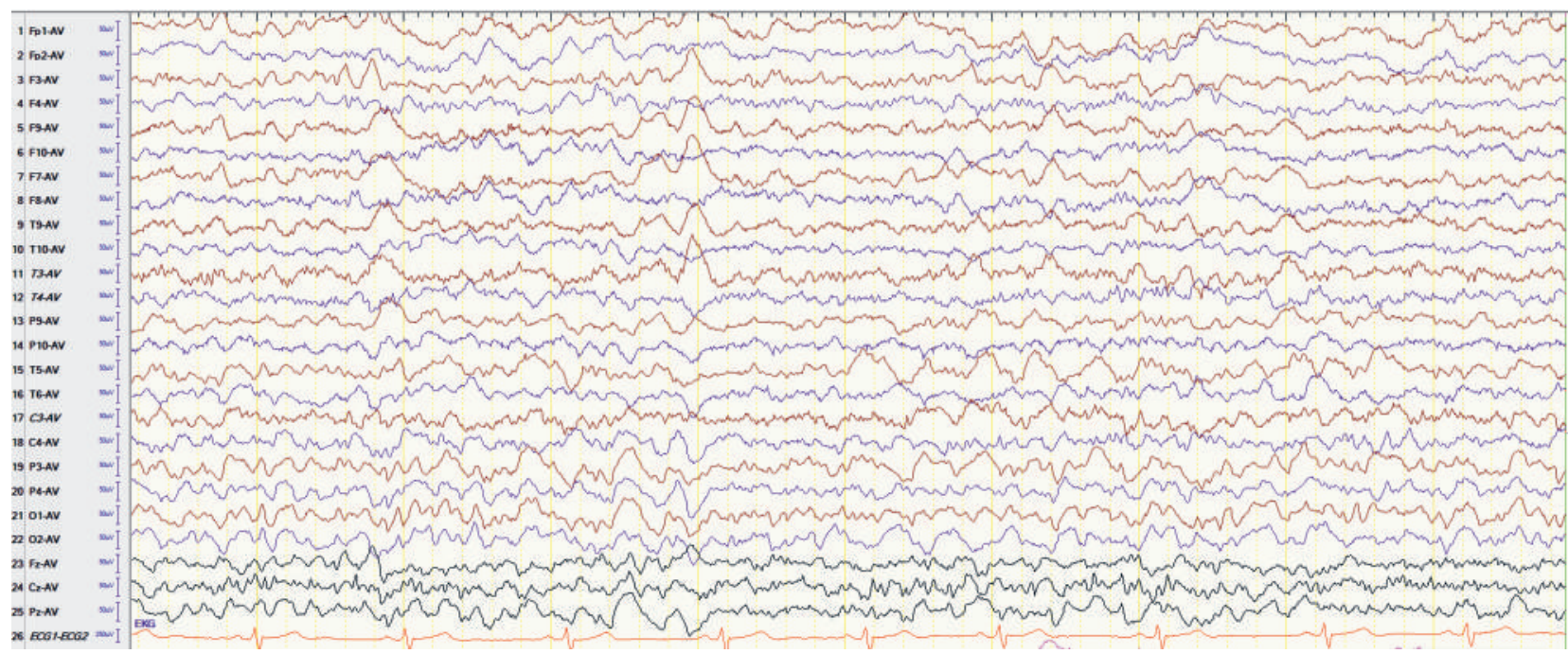

4 pav. EEG: patologinis lėtas aktyvumas kairiajame pusrutulyje

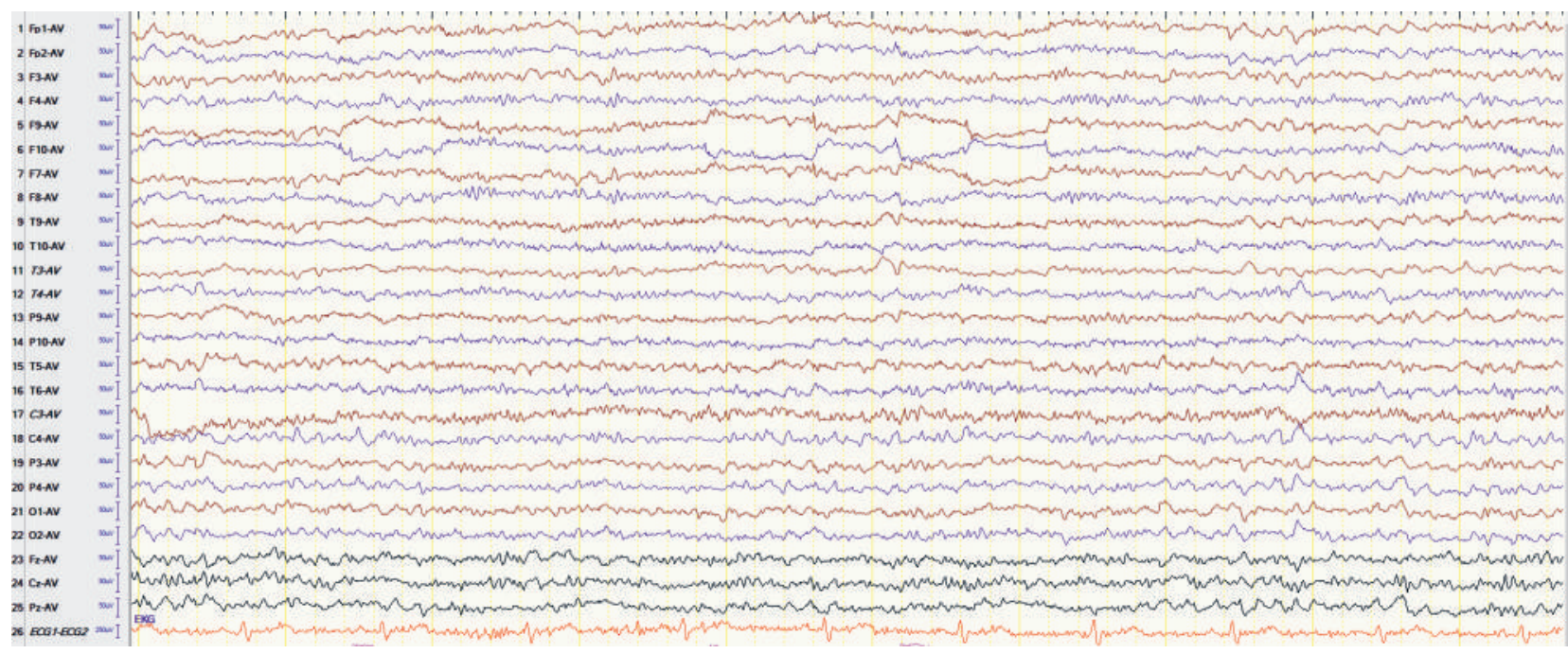

5 pav. EEG kognityvinių užduočių metu: patologinis lètas aktyvumas neregistruojamas 


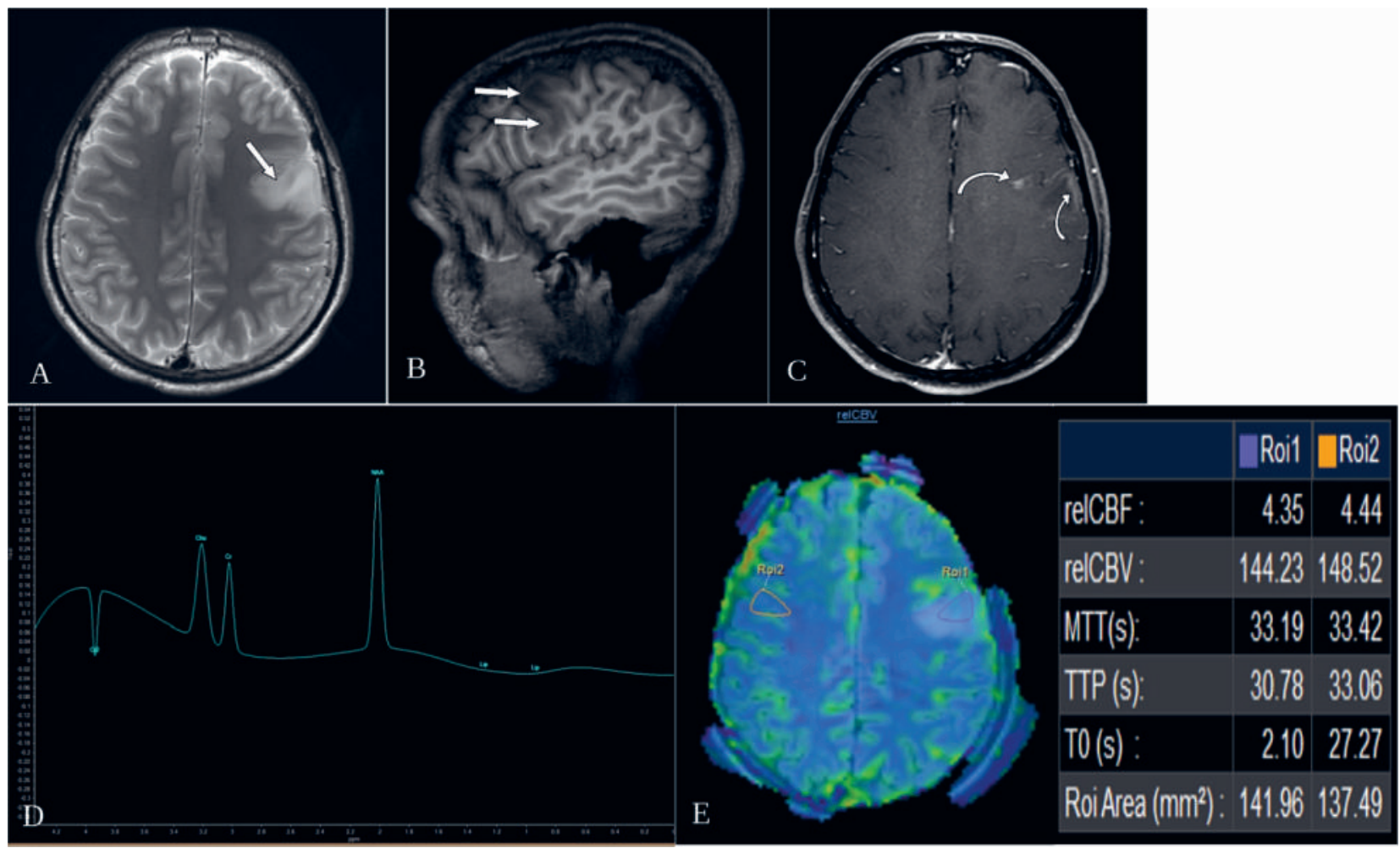

6 pav. Galvos smegenų MRT šeštą hospitalizacijos dieną.

A - T2 TSE ir B - T1 vaizduose matoma, kad pakitimų apimtis nežymiai platesnė (rodyklès); C - pokontrastiniuose T1 vaizduose dinamikoje pasikeitęs kontrastinės medžiagos kaupimas, atsirado naujų kaupiančių sričių žievėje (lenktos rodyklès); D - MR spektroskopijos duomenimis, NAA/Cr santykis - 2,06, Cho/NAA - 0,77, atitinkantys normalius dydžius; E - perfuzijos sekoje CBV rodikliai, lyginant su kontralateraline puse, yra panašūs.

Po 6 mėnesių atlikto MRT vaizduose buvo stebima ryškiai teigiama dinamika: židinys kairiojoje kaktinejje skiltyje žymiai sumažèjo, išnyko perifokalinė edema, buvusių pakitimų srityje liko nedideli pakitimai, kur žievė plonesnè, T2 hiperintensinio signalo (7 pav.).

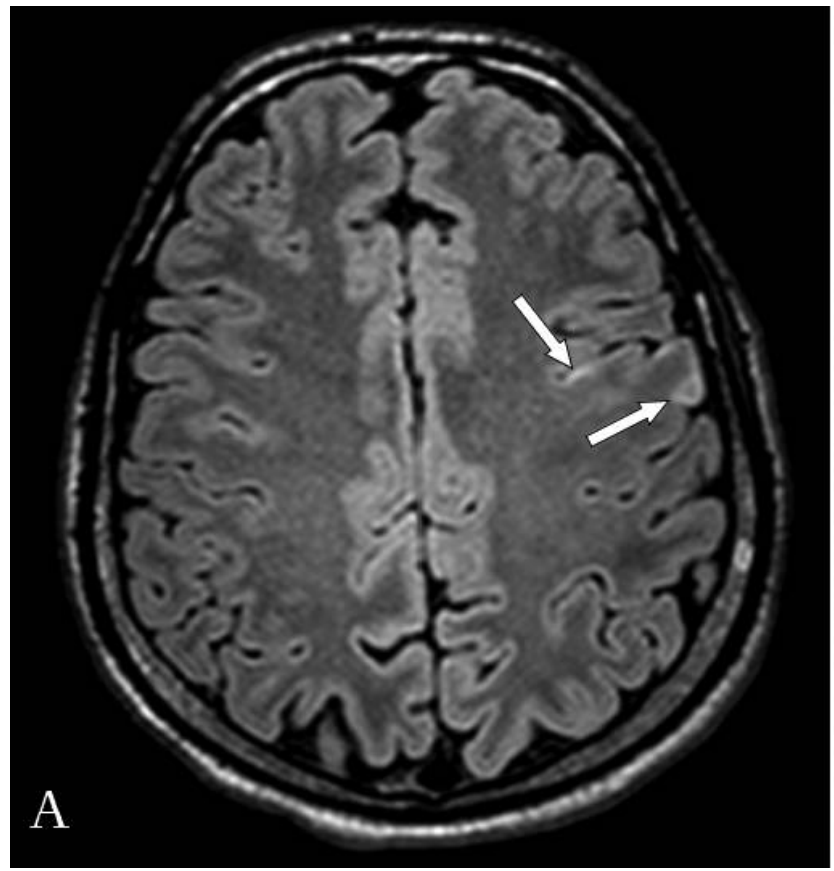

Praejjus beveik dvejiems metams nuo ligos pasireiškimo, ligonio neurologinė būklè išliko be patologinių pokyčių, o atlikus EEG patologinis aktyvumas foninejje EEG ir provokacinių mėginių metu neregistruotas (8 pav.).

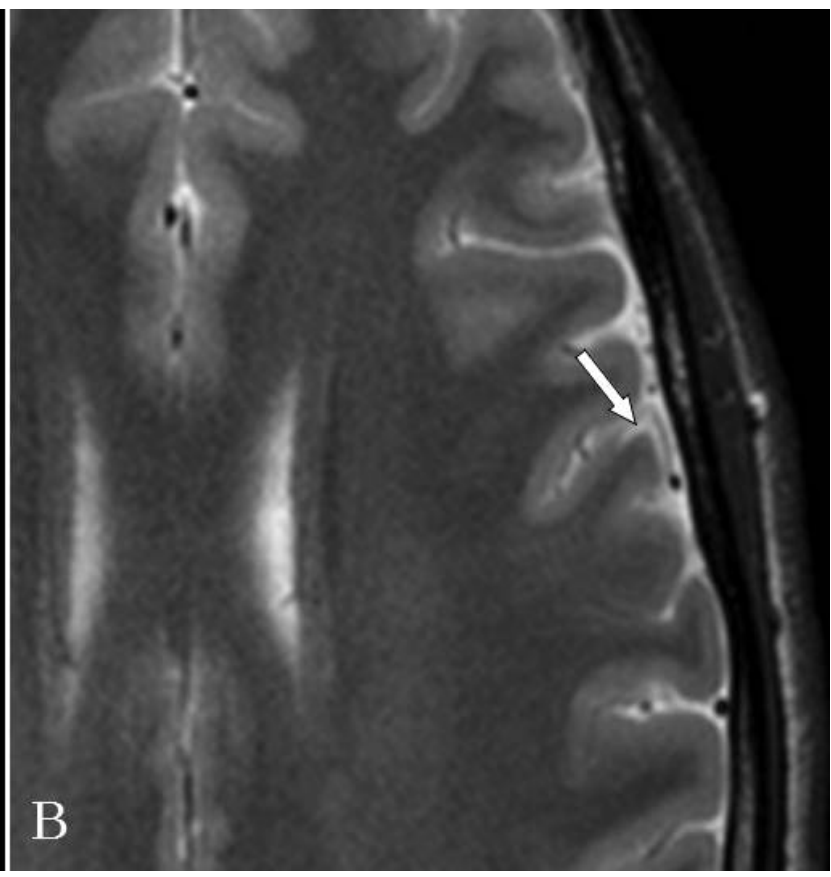

7 pav. Galvos smegenų MRT po 6 mẻnesių.

A - T2 FLAIR ir B - T2 TSE vaizduose buvusių pakitimų zonoje nedideli lokalūs glioziniai pakitimai žievèje (rodyklès) 


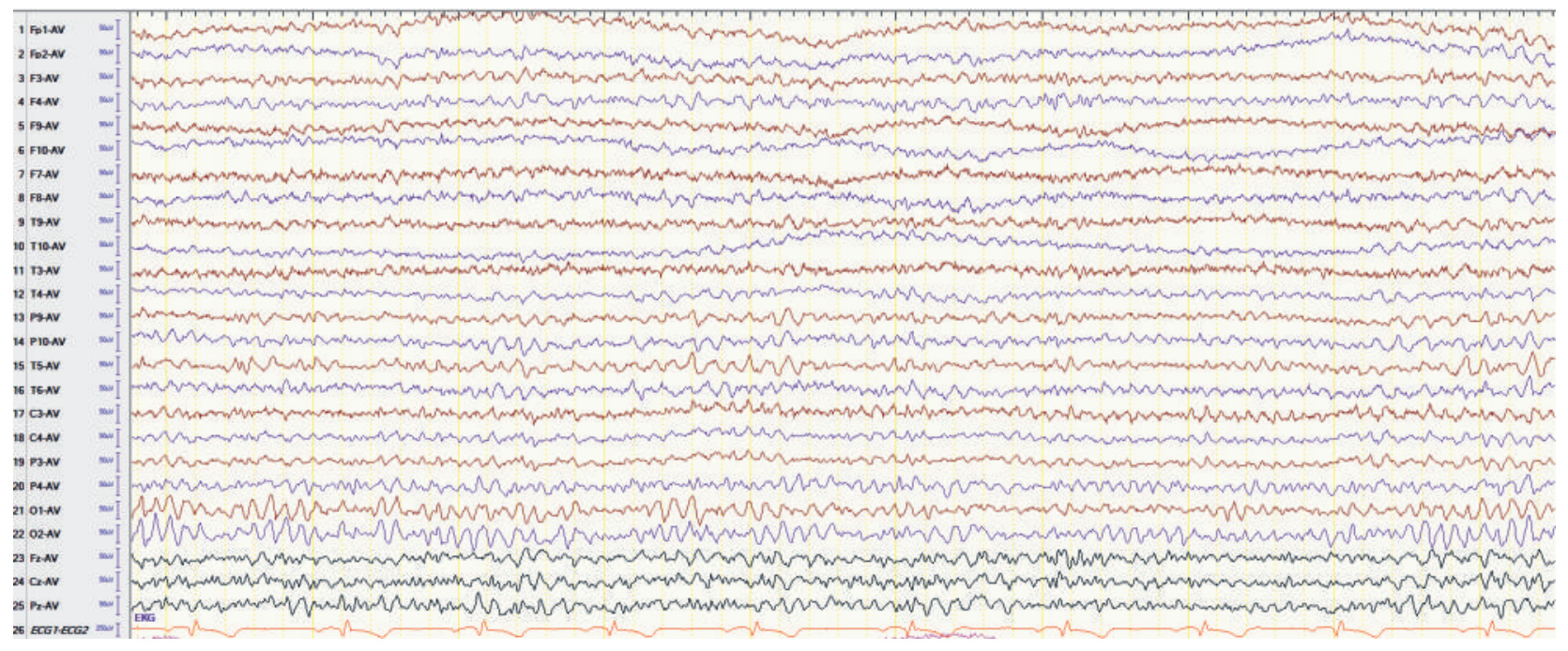

8 pav. EEG po 6 mẻnesių. Norma

\section{EEG POKYČIAI INFEKCINIO IR AUTOIMUNINIO ENCEFALITO ATVEJU}

Žinomi vos keli infekciniai CNS susirgimai, kurių metu registruojami sukėlejui būdingi EEG pokyčiai: Herpes simplex- 1 sukeltas encefalitas, tymų viruso sukeltas poūmis sklerozuojantis panencefalitas (angl. subacute sclerosing panencephalitis, SSPE) ir Creutzfeldt-Jakob liga [9].

HSV-1 yra dažniausias infekcinio encefalito sukèlëjas $[10,11]$. Literatūroje aprašytas HSV-1 encefalitui būdingų EEG pokyčių specifiškumas skiriasi. Dažniausi HSV-1 encefalito EEG pokyčiai yra židininis delta aktyvumas ir vienpusiai ar abipusiai periodiniai epilepsiforminiai iškrūviai (angl. periodic epileptiform discharge, $\mathrm{PED}$ ) temporalinėse skiltyse $[9,12,13]$. PED atsiranda $2-15$ parą ir neretai gali būti aptinkami anksčiau nei HSV-1 encefalitui būdingi struktūriniai pokyčiai neurovizualiniuose tyrimuose [14]. Nors abipusiai epilepsiforminiai iškrūviai HSV-1 encefalito metu yra susiję su blogesnėmis neurologinėmis išeitimis, patikimų literatūros duomenų, susijusių su prognostiniais EEG pokyčiais, trūksta. Teigiama, kad ankstyvas gydymas antivirusiniais vaistais sumažina PED išsivystymo tikimybę $[9,15]$.

Sergant ne-HSV sukeltu infekciniu meningoencefalitu, pokyčiai EEG yra nespecifiški: pradžioje lètėja alfa bangụ ritmas, o pažeidimui progresuojant, atsiranda teta ir delta aktyvumas [9]. Nors, itariant encefalitą, Tarptautinio encefalito konsorciumo gairèse ( 2 lentelè) rekomenduojama atlikti EEG, diagnostinè ir prognostinè tyrimo vertė, trūkstant patikimų mokslinių tyrimų, išlieka ne iki galo aiški $[14,16]$. Remiantis $2015 \mathrm{~m}$. atliktu 76 pacientų imties tyrimu, stebimi EEG pokyčiai statistiškai reikšmingai skyrèsi tarp HSV ir ne-HSV sukelto infekcinio encefalito: PED ir sulètėjimo židinių buvimas frontotemporalinèse ir pakaušinėje srityse buvo kur kas dažniau susijęs su HSE [14].

SSPE yra mirtinas tymų viruso sukeltas CNS uždegimas, kuris išsivysto vidutiniškai praejus 4-8 metams nuo pirminès tymų infekcijos [17]. Klasikiniai SSPE pokyčiai EEG yra abipusiai, simetriški periodiniai smailių-lètų ban- gų kompleksai, kurių periodiškumas svyruoja nuo kelių iki keliasdešimt sekundžių, tačiau dažniausiai pasikartoja kas 4-10 sekundžių. Dažnai kiekvieną jų kliniškai lydi miokloniniai raumenų trūkčiojimai [11]. Ligai progresuojant, intervalas tarp kompleksų mažejja, kol galiausiai visai išnyksta - tai glaudžiai koreliuoja su klinikiniu būklès blogėjimu $[9,18,19]$. Ligos pradžioje tarp kompleksų registruojamas normalus foninis smegenų aktyvumas, kuris lètėja progresuojant SSPE [9]. Aprašyti klasikiniai EEG pakitimai labiau būdingi vaikams ir paaugliams, bet jei iki susergant SSPE vaikas turejjo neurologini pažeidimą (pirmaisiais gyvenimo metais persirgo nespecifiniu virusiniu encefalitu, turejjo igimtą neurosensorinị kurtumą, diagnozuotą sunkų mokymosi sutrikimą), be icprastų SSPE pokyčių, EEG gali būti registruojami ir židininiai epilepsiforminiai iškrūviai bei stebimi klinikiniai židininiai priepuoliai

\section{2 lentelè. Infekcinės kilmès encefalito diagnostiniai kriterijai}

\section{Didysis kriterijus (būtinas)}

1) Protinès būklès sutrikimas, kuris pasireiškia sumažèjusiu ar pakitusiu sąmonės lygiu, mieguistumu ar asmenybės pokyčiais, ir trunka 24 valandas ar ilgiau, nesant alternatyvios encefalitui priežasties.

Mažieji kriterijai (2 kriterijai reikalingi galimam encefalitui (angl. possible encephalitis), $\geq 3$ kriterijai reikalingi tikètinam (angl. probable encephalitis) ar patvirtintam encefalitui)

1) Karščiavimas $\geq 38^{\circ} \mathrm{C}$, pasireiškęs per 72 valandas prieš (po) ligos pasireiškimą.

2) Generalizuoti arba židininiai epilepsijos priepuoliai, kurie negali būti priskiriami prieš tai buvusiam epilepsiniam sindromui.

3) Naujai pasireiškę židininiai neurologiniai simptomai.

4) Leukocitų skaičius likvore $-\geq 5 / \mathrm{mm}^{3}$.

5) Encefalitui būdingi naujai atsiradę smegenų parenchimos pokyčiai kompiuterinès tomografijos ar magnetinio rezonanso tomografijos vaizduose.

6) Pakitimai elektroencefalogramoje, leidžiantys įtarti encefalitą ir neturintys kito paaiškinimo. 
[19]. Suaugusieji SSPE serga rečiau, o pakitimai EEG taip pat dažniau netipiški (registruojamas lètas smegenų aktyvumas be stereotipinių kompleksų) [9].

Creutzfeldt-Jakob liga (CJD) - kita mirtina degeneracinè smegenų liga, sukeliama patologinio baltymo priono. Ji priklauso spongiforminès encefalopatijos ligu grupei. Išskiriamos keturios CJD formos: sporadinè, jatrogeninè, šeiminė ir variantinè (angl. variant). Sporadinė CJD yra dažniausia ligos forma, sudaranti $85 \%$ visų ligos atvejų (1 atvejis/1 mln. gyventojų), galimai kylanti dẻl spontaninės baltymą prioną koduojančio geno mutacijos ar baltymo struktūros pokyčio [20]. Sporadinès CJD metu 60-70 \% EEG registruojami itin būdingi periodiniai trifaziai (rečiau bifaziai ar mišrūs) smailių bangų kompleksai (angl. periodic sharp wave complexes, PSWC), dažniausiai būdravimo metu. Jie yra linkę išnykti ligoniui miegant ir gali būti maskuojami benzodiazepinų, kurie neretai skiriami CJD sukeltiems traukuliams slopinti. PSWC nekoreliuoja su CJD klinikai būdingomis mioklonijomis [20, 21]. EEG pokyčiai jatrogeninès CJD atveju yra panašūs į sporadinès CJD, tačiau ịvairuoja nuo lokalizuoto lèto smegenu aktyvumo infekcijos vietoje iki tipiškų PSWC. Sergant šeimine CJD forma, būdingų PSWC užrašymo dažnis priklauso nuo mutacijos vietos baltymo priono gene ir siekia apie $10 \%$, o variantinès CJD metu PSWC neaptikimas EEG yra laikomas vienu iš diagnostinių kriterijų [21].

Be infekcinès kilmès encefalitų, verta paminèti ir autoimuninị encefalitą, kurị sukelia antikūnai prieš N-metilD-aspartato receptorius (anti-NMDAR). Literatūros duomenimis, anti-NMDAR encefalitas sudaro $4 \%$ (2 atvejai/1 mln. gyventojų), o autoimuniniai encefalitai bendrai apie 20-30\% visų encefalito atvejų [22]. EEG atlieka svarbų vaidmenį, diferencijuojant pirminę psichiatrinę patologiją nuo autoimuninio encefalito sukeltų elgesio sutrikimų. Pakitimai EEG anti-NMDAR encefalito metu pasireiškia 90-100 \% ligonių, dažniausiai (60-83 \%) registruojamas nespecifinis encefalopatijai būdingas lètas dezorganizuotas smegenų aktyvumas, iki $50 \%$ aptinkamas epilepsinis aktyvumas [22-24]. 30-50 \% suaugusių ligonių EEG registruojami anti-NMDAR encefalitui specifiški „delta šepetèliai““ (angl. extreme delta brush) - ritmiškas $1-3 \mathrm{~Hz}$ delta aktyvumas, persidengiantis su $20-30 \mathrm{~Hz}$ beta aktyvumu [25, 26]. Šio pokyčio užrašymas EEG asocijuojamas su prastesne prognoze ir ilgesniu hospitalizacijos laiku [27]. Visgi, kai kurie autoriai kritikuoja „delta šepetèlį" dèl studijų, įvertinančių šio fenomeno jautrumą, trūkumo ir rekomenduoja anti-NMDAR encefalito diagnostikoje naudoti beta ir delta santyki (angl. beta/delta power ratio, BDPR), kurio padidèjimas yra dažnesnis ir mažiau priklausomas nuo ligos stadijos [23, 28].

\section{KANAPIŲ VARTOJIMO POVEIKIS IMUNINEI SISTEMAI IR EPILEPSIJOS PRIEPUOLIAMS}

Šiame straipsnyje apžvelgti galimą kanapių poveikị paskatino ligonio anamnezejje nurodyta 10 metų kanapių vartojimo trukmè. Literatūroje plačiausiai aprašomas pagrindinio biologiškai aktyvaus kanapėse randamo junginio, delta9-tetrahidrokanabinolio (THC), imunomoduliacinis (daugiausia imunosupresinis) poveikis, prisijungiant prie 2 tipo kanabinoidų receptorių (CB2R), išsidèsčiusių imuninių ląstelių paviršiuje [29]. Eksperimentiniuose tyrimuose su pelèmis ir jūrų kiaulytèmis įrodytas nuo dozès priklausomas THC imunosupresinis poveikis prieš virusų, bakteriju ir pirmuonių sukeltas infekcijas [30, 31]. HSV-2 neutralizuojančių antikūnų kiekio sumažèjimas pelèse, paveiktose THC, lyginant su kontroline grupe, prilygsta ciklofosfamido poveikiui [30], mikroglijos reakcija ị gramneigiamu bakterijų lipopolisacharidus, gaminant prouždegiminius citokinus (IL-1, IL-6, TNF alfa), yra silpnesnè [32], o mirštamumas nuo oportunistinių pirmuonių sukeltos CNS infekcijos - didesnis [31]. Nepaisant to, literatūroje trūksta informacijos apie imunosupresinị kanapių poveikị žmonẻms, o tiesioginiu įrodymų, kad kanapių vartojimas didina neuroinfekcijų dažni, šiuo metu nèra.

Nemažiau prieštaringas išvadas pateikia ir tyrimai, analizuojantys kanapių poveiki epilepsiniams traukuliams. Nors gyvūnų modeliai rodo galimą THC traukulius skatinantị poveikị [33] ir nuo dozės priklausomą THC neurotoksiškumą smegenų dalims, kuriose daugiausia 1 tipo kanabinoidų receptorių (CB1R; hipokampe, migdoliniame kūne, pertvaroje, galvos smegenų žievejje), tačiau tyrimų, patvirtinančių tokị kanapių poveikị žmogaus smegenims, rezultatai yra nevienareikšmiai [34]. Kiek aiškesnius duomenis pateikia sintetinių kanabinoidų, keliasdešimt kartu stipriau veikiančiu CB1/CB2 receptorius, tyrimai. Tait ir kt. sisteminėje apžvalgoje nurodo, kad toninių-kloninių traukulių dažnis tarp asmenų, vartojusių sintetinius kanabinoidus ir patekusių į ligoninę, svyruoja nuo 3,8 iki $15 \%$ ir yra didesnis jaunesnio amžiaus pacientu grupejje [35]. Gounder ir kt. aprašè 30 pacientų, kuriuos per 24 val. nuo sintetinių kanabinoidų vartojimo ištiko traukulių priepuoliai. $80 \%$ asmenų jie pasireiškè per 12 valandų, $90 \%$ atvejų sudarè toniniai-kloniniai priepuoliai, $10 \%$ - židininiai priepuoliai su sąmonès sutrikimu. Iš 26 pacientų, kuriems buvo atliktas neurovizualinis tyrimas, trims rastas epileptogeninis židinys galvos smegenyse. Aštuoniems stebèti pakitimai EEG. Pacientams, kurie prieš sintetiniu kanabinoidų vartojimą nebuvo patyrę priepuolio, neturejjo rizikos veiksnių ir po priepuolio nutraukè jų vartojimą, traukulių pasikartojimo dažnis siekè $8 \%$. Šis dažnis, straipsnio autoriu, prilyginamas amfetamino sukeltam traukulių pasikartojimo dažniui (7 \%) [36].

\section{PANAŠŪS ATVEJAI LITERATŪROJE}

Literatūroje galima rasti vos kelis aprašytus atvejus, kai suaugusiam imunokompetentiškam pacientui encefalitas imitavo glialinį CNS naviką. T. Peeraully ir kt. aprašè 54 metų moterị, ị prièmimo skyrių atvykusią su poūmiai išsivysčiusiu sąmonès ir kalbos sutrikimu, galvos skausmu ir $15 \mathrm{~kg}$ svorio netekimu per vienerius metus. Atlikus GSKT ir MRT, buvo rasti patologiniai pokyčiai kairèje temporalinèje ir frontalinejje skiltyse, panašǔs ị infiltruo- 
jančią gliomą. Itarimą sustiprino MRT spektroskopijos (aptiktas Cho koncentracijos padidejimas) ir perfuzijos (aptiktos fragmentiškos hipoperfuzijos zonos) tyrimai. Dẻl galimos smegenų strigimo rizikos pasirinkta atlikti kraniotomiją ir smegenų biopsiją, kuri patvirtino HSV-1 encefalito diagnozę [37].

D. Panagopoulos ir kt. aprašè kitą atveji, kai 5 metų pacientei su silpnai išreikšta ataksija, nistagmu ir galūnių tremoru dèl priešlaikinès telarchès atlikus galvos smegenų MRT buvo atsitiktinai rastas $23 \mathrm{~mm}$ dydžio židinys dešiniajame smegenėlių pusrutulyje ir nežymūs kairès temporalinès srities pokyčiai T2 sekoje. Minimu atveju buvo atliktas MRT spektroskopijos tyrimas, kuriame aptikti žemo laipsnio gliomos įtarimą sustiprinantys pokyčiai: Cho padidejjimas, NAA sumažẻjimas, NAA/Cr santykis 0,89, $\mathrm{Cho} / \mathrm{Cr}-1,41$ ir Cho/NAA - 1,58. Po kelių dienų nutarta šalinti smegenèlèse esanti darinị, tačiau intraoperacinès biopsijos mėginiuose navikui būdingų pokyčių nerasta. Iškart po operacijos atliktoje GSKT aptiktas gerai apribotas židinys tame pačiame smegenèliu pusrutulyje, todèl dèl liekamojo naviko ịtarimo operacija ir biopsija buvo pakartotos (histologinė išvada nepakito). Po operacijos dẻl išsivysčiusiụ toniniụ-kloninių traukulių užrašyta EEG, stebėtas lètas dezorganizuotas smegenų aktyvumas. Pacientei febriliai sukarščiavus, ịtarta neuroinfekcija ir, atlikus likvoro tyrimus, patvirtinta HSV-1 encefalito diagnozė [38].

\section{APIBENDRINIMAS}

Mūsų aprašomu atveju EEG tapo svarbiausia diagnostine priemone, nukreipusia teisingos encefalito diagnozès link. Atliktoje galvos smegenų MRT stebėti pokyčiai buvo būdingi gliomai su galima piktybine transformacija. Visgi, užrašius EEG, buvo pastebèta neatitiktis tarp MRT vaizduose matomo pažeidimo lokalizacijos ir radinių EEG. Ši neatitiktis sukėlè abejonių dèl naviko diagnozès. MRT spektroskopijoje stebėta ịprasta NAA, Cho bei Cr koncentracija ir likvore rastas leukocitu skaičiaus padidejimas, dominuojant monomorfonuklearams, taip pat parèmé encefalito diagnozę. Nors encefalito sukèlèjas mūsų aprašomu atveju nebuvo nustatytas, HSV-1 encefalito diagnozé, kaip ir CJD ar SSPE, šiuo atveju yra mažai tikètina dèl netipiškų MRT ir EEG pokyčių bei gerybinès ligos eigos. Vis dèlto, galbūt atliktas papildomas likvoro PGR tyrimas būtų padejjęs nustatyti ligos sukèlejją.

\section{IŠVADOS}

EEG yra plačiai prieinamas ir svarbus diagnostinis tyrimas, esant neaiškiai klinikinei situacijai, diferencijuojant pirmą kartą icvykusių epilepsijos priepuolių priežastį. Esant histologiškai nepatvirtintai galvos smegenų naviko diagnozei, EEG gali tapti svarbiausiu diagnostiniu metodu, padedančiu ịtarti atipinị encefalitą. Pakartotinio EEG tyrimo analizė padeda vertinti ligos dinamiką ir numatyti išeitis.

\section{Literatūra}

1. Samudra N, Zacharias T, Plitt A, et al. Seizures in glioma patients: an overview of incidence, etiology, and therapies. J Neurol Sci 2019; 404: 80-5. https://doi.org/10.1016/ j.jns.2019.07.026

2. Englot DJ, Chang EF, Vecht CJ. Epilepsy and brain tumors. Handb Clin Neurol 2016; 134: 267-85. https://doi.org/ 10.1016/B978-0-12-802997-8.00016-5

3. Zhao L, Zhou M, Wang B, et al. Clinical characteristics and outcome of clinically diagnosed viral encephalitis in southwest China. Neurol Sci 2015; 36: 2191-7. https://doi.org/ 10.1007/s10072-015-2333-8

4. Misra UK, Kalita J. Seizures in encephalitis: predictors and outcome. Seizure 2009; 18: 583-7. https://doi.org/10.1016/ j.seizure.2009.06.003

5. Hussein AS, Shafran SD. Acute bacterial meningitis in adults: a 12-year review. Medicine (Baltimore) 2000; 79: 360-8. https://doi.org/10.1097/00005792-200011000-00002

6. Durand ML, Calderwood SB, Weber DJ, et al. Acute bacterial meningitis in adults - a review of 493 episodes. N Engl J Med 1993; 328: 21-8. https://doi.org/10.1056/ NEJM199301073280104

7. Misra UK, Tan CT, Kalita J. Viral encephalitis and epilepsy. Epilepsia 2008; 49: 13-8. https://doi.org/10.1111/ j.1528-1167.2008.01751.x

8. Sili U, Kaya A, Mert A, et al. Herpes simplex virus encephalitis: clinical manifestations, diagnosis and outcome in 106 adult patients. J Clin Virol 2014; 60: 112-8. https://doi.org/ 10.1016/j.jcv.2014.03.010

9. Smith SJM. EEG in neurological conditions other than epilepsy: when does it help, what does it add? J Neurol Neurosurg Psychiatry 2005; 76(Suppl 2): ii8-12. https://doi.org/10.1136/jnnp.2005.068486

10. George BP, Schneider EB, Venkatesan A. Encephalitis hospitalization rates and inpatient mortality in the United States, 2000-2010. PLoS One 2014; 9: e104169. https://doi.org/ 10.1371/journal.pone.0104169

11. Mailles A, Stahl J-P. Infectious encephalitis in France in 2007: a national prospective study. Clin Infect Dis 2009; 49: 1838-47. https://doi.org/10.1086/648419

12. Lai CW, Gragasin ME. Electroencephalography in herpes simplex encephalitis. J Clin Neurophysiol 1988; 5: 87-104. https://doi.org/10.1097/00004691-198801000-00003

13. Smith JB, Westmoreland BF. A distinctive clinical EEG profile in herpes simplex encephalitis. Mayo Clin Proc 1975; 50: 469-74.

14. Sutter R, Kaplan PW, Cervenka MC, et al. Electroencephalography for diagnosis and prognosis of acute encephalitis. Clin Neurophysiol 2015; 126: 1524-31. https://doi.org/ 10.1016/j.clinph.2014.11.006

15. Gavrilovic A, Drakulic SM, Matic TB, et al. EEG abnormalities as diagnostic and prognostic factor for encephalitis. Serbian J Exp Clin Res 2016; 17: 225-9. https://doi.org/ 10.1515/sjecr-2016-0018

16. Venkatesan A, Tunkel AR, Bloch KC, et al. Case definitions, diagnostic algorithms, and priorities in encephalitis: consensus statement of the international encephalitis consortium. Clin Infect Dis 2013; 57: 1114-28. https://doi.org/10.1093/ cid/cit458

17. Tunkel AR, Glaser CA, Bloch KC, et al. The management of encephalitis: clinical practice guidelines by the Infectious Diseases Society of America. Clin Infect Dis 2008; 47: 303-27. https://doi.org/10.1086/589747 
18. Buchanan R, Bonthius DJ. Measles virus and associated central nervous system sequelae. Semin Pediatr Neurol 2012; 19(3): 107-14. https://doi.org/10.1016/j.spen.2012.02.003

19. Gadoth N. Subacute sclerosing panencephalitis (SSPE) the story of a vanishing disease. Brain Dev 2012; 34(9): 705-11. https://doi.org/10.1016/j.braindev.2011.12.008

20. Manix M, Kalakoti P, Henry M, et al. Creutzfeldt-Jakob disease: updated diagnostic criteria, treatment algorithm, and the utility of brain biopsy. Neurosurg Focus 2015; 39: 2076-84. https://doi.org/10.3171/2015.8.FOCUS15328

21. Wieser HG, Schindler K, Zumsteg D. EEG in CreutzfeldtJakob disease. Clin Neurophysiol 2006; 117: 935-51. https://doi.org/10.1016/j.clinph.2005.12.007

22. Venkatesan A, Michael BD, Probasco JC, et al. Acute encephalitis in immunocompetent adults. Lancet 2019; 393: 702-16. https://doi.org/10.1016/S0140-6736(18)32526-1

23. Freund B, Ritzl EK. A review of EEG in anti-NMDA receptor encephalitis. J Neuroimmunol 2019; 332: 64-8. https://doi.org/10.1016/j.jneuroim.2019.03.010

24. Gillinder L, Warren N, Hartel G, et al. EEG findings in NMDA encephalitis - a systematic review. Seizure 2019; 65: 20-4. https://doi.org/10.1016/j.seizure.2018.12.015

25. Schmitt SE, Pargeon K, Frechette ES, et al. Extreme delta brush. A unique EEG pattern in adults with anti-NMDA receptor encephalitis. Neurology 2012; 79(11): 1094-100. https://doi.org/10.1212/WNL.0b013e3182698cd8

26. Huang Q, Wu Y, Qin R, et al. Clinical characteristics and outcomes between children and adults with anti-N-Methyl-dAspartate receptor encephalitis. J Neurol 2016; 263: 2446-55. https://doi.org/10.1007/s00415-016-8282-1

27. Warren N, Siskind D, O'Gorman C. Refining the psychiatric syndrome of anti-N-methyl-d-aspartate receptor encephalitis. Acta Psychiatr Scand 2018; 138: 401-8. https://doi.org/ 10.1111/acps. 12941

28. Foff EP, Taplinger D, Suski J, et al. EEG findings may serve as a potential biomarker for anti-NMDA receptor encephalitis. Clin EEG Neurosci 2017; 48: 48-53. https://doi.org/ $10.1177 / 1550059416642660$

29. Cabral GA, Jamerson M. Marijuana use and brain immune mechanisms. Int Rev Neurobiol 2014; 118: 199-230. https://doi.org/10.1016/B978-0-12-801284-0.00008-7

30. Cabral GA, Dove Pettit DA. Drugs and immunity: cannabinoids and their role in decreased resistance to infectious disease. J Neuroimmunol 1998; 83: 116-23. https://doi.org/10.1016/S0165-5728(97)00227-0

31. Cabral GA, Raborn ES, Griffin L, et al. CB 2 receptors in the brain: role in central immune function. Br J Pharmacol 2008; 153: 240-51. https://doi.org/10.1038/sj.bjp.0707584

32. Puffenbarger RA, Boothe AC, Cabral GA. Cannabinoids inhibit LPS-inducible cytokine mRNA expression in rat microglial cells. Glia 2000; 29: 58-69.
https://doi.org/10.1002/(SICI)1098-1136(20000101)29:1<5 $8::$ AID-GLIA6 $>3.0 . \mathrm{CO} ; 2-\mathrm{W}$

33. Devinsky O, Cilio MR, Cross H, et al. Cannabidiol: pharmacology and potential therapeutic role in epilepsy and other neuropsychiatric disorders. Epilepsia 2014; 55: 791-802. https://doi.org/10.1111/epi.12631

34. Lorenzetti V, Lubman DI, Whittle S, et al. Structural MRI findings in long-term cannabis users: what do we know. Subst Use Misuse 2010; 45: 1787-808. https://doi.org/ $10.3109 / 10826084.2010 .482443$

35. Tait RJ, Caldicott D, Mountain D, et al. A systematic review of adverse events arising from the use of synthetic cannabinoids and their associated treatment. Clin Toxicol 2016; 54: 1-13. https://doi.org/10.3109/15563650. 2015.1110590

36. Gounder K, Dunuwille J, Dunne J, et al. The other side of the leaf: Seizures associated with synthetic cannabinoid use. Epilepsy Behav 2020; 104(Pt A): 106901. https://doi.org/ 10.1016/j.yebeh.2020.106901

37. Peeraully T, Landolfi JC. Herpes encephalitis masquerading as tumor. ISRN Neurol 2011; 2011: 1-4. https://doi.org/ $10.5402 / 2011 / 474672$

38. Panagopoulos D, Themistocleous M, Apostolopoulou K, et al. Herpes simplex encephalitis initially erroneously diagnosed as glioma of the cerebellum: case report and literature review. World Neurosurg 2019; 129: 421-7. https://doi.org/ 10.1016/j.wneu.2019.06.158

\section{Jokubaitis, R. Mameniškienė, A. Barkauskienė, J. Valaikienè}

\section{VALUE OF EEG IN THE DIFFERENTIATION OF GLIAL TUMOR AND ENCEPHALITIS: A CASE REPORT AND REVIEW OF LITERATURE}

\section{Summary}

We report a case of a 24-year-old acute encephalitis patient presenting with epileptic seizures. Glial tumor was suspected due to initial changes seen on magnetic resonance imaging. The findings of electroencephalography (EEG) were indicative of a functional impairment, therefore additional tests were performed that revealed changes characteristic for inflammation. In this case of histologically unconfirmed diagnosis of brain tumor, EEG became the most significant method for suspecting atypical encephalitis. The article also reviews similar cases described in the literature and EEG changes characteristic of infectious and autoimmune encephalitis.

Keywords: electroencephalography, EEG, neuroinfection, encephalitis, glioma, cannabinoids.

Gauta:

20200819
Priimta spaudai: 20200914 